\title{
ACORN DISPERSAL BY CALIFORNIA SCRUB-JAYS IN URBAN SACRAMENTO, CALIFORNIA
}

\author{
DANIEL A. AIROLA, Conservation Research and Planning, 114 Merritt Way, Sac- \\ ramento, California 95864; d.airola@sbcglobal.net
}

\begin{abstract}
California Scrub-Jays (Aphelocoma californica) harvest and cache acorns as a fall and winter food resource. In 2017 and 2018, I studied acorn caching by urban scrub-jays in Sacramento, California, to characterize oak and acorn resources, distances jays transport acorns, caching's effects on the jay's territoriality, numbers of jays using acorn sources, and numbers of acorns distributed by jays. Within four study areas, oak canopy cover was $<1 \%$, and only $19 \%$ of 126 oak trees, $92 \%$ of which were coast live oaks (Quercus agrifolia), produced acorns. Jays transported acorns for $\geq 117$ days. Complete $(28 \%)$ and partially recorded $(72 \%)$ flights from acorn sources to caching sites averaged $160 \mathrm{~m}$ and ranged up to $670 \mathrm{~m}$. Acorntransporting jays passed at tree-top level above other jays' territories without eliciting defense. At least 20 scrub-jays used one acorn source in one 17.5-ha area, and $\geq 13$ jays used another 4.7-ha area. Jays cached an estimated 6800 and 11,000 acorns at two study sites (mean 340 and 840 acorns per jay, respectively), a rate much lower than reported in California oak woodlands, where harvest and caching are confined within territories. The lower urban caching rate may result from a scarcity of acorns, the time required for transporting longer distances, and the availability of alternative urban foods. Oaks originating from acorns planted by jays benefit diverse wildlife and augment the urban forest.
\end{abstract}

The California Scrub-Jay (Aphelocoma californica) is common in oak woodlands and residential areas in the Pacific states (Beedy and Pandolfino 2013, Curry et al. 2017). In central California, the species declined during the mid-2000s as a result of West Nile virus (Airola et al. 2007, Wheeler et al. 2009), but it appears to have recovered (Pandolfino 2017). Despite its abundance, the California Scrub-Jay has attracted fewer ecological studies than have its more threatened sister species, the Florida Scrub-Jay ( $A$. coerulescens; Woolfenden and Fitzpatrick 1996) and Island Scrub-Jay (A. insularis; Curry and Delaney 2002, Caldwell et al. 2013). The primary ecological study of the California Scrub-Jay took place in a coastal California oak woodland (Carmen 2004).

The California Scrub-Jay's acorn-caching behavior is widely known, noted as early as the late 1800s in Mark Twain's fanciful Jim Baker's Bluejay Yarn (Clemens 1875). In California oak woodlands, individual scrubjays cache approximately 7000 acorns per year, which serve as a critical food resource during fall and winter (Carmen 2004). The species' social organization there consists of territorial pairs and nonterritorial floaters. In areas with an adequate supply of acorns, Carmen (2004) reported territory sizes varying from 0.7 to 6.5 ha and averaging $2.2-2.5$ ha. Territorial birds harvest and cache acorns almost entirely within the territories they occupy year round, unless the acorn crop fails, when some territories are abandoned (Carmen 2004).

The importance of oaks to the various scrub-jay species, and jays' important ecosystem roles in dispersing and caching acorns, have long been recognized (Grinnell 1936, Griffin 1971, DeGange et al. 1989, Carmen 
2004, Curry et al. 2017). For example, Morrison et al. (2011) and Pesendorfer et al. (2016b) have shown that seed dispersal by the Island Scrub-Jay has a key role in restoring oak and pine woodlands on Santa Cruz Island.

Ecological information on urban California Scrub-Jays is limited. Blair (1996) reported the jays to be more abundant in suburbs with a low density of buildings than in natural oak woodland. Many urban areas in the species' range are dominated by non-native ornamental trees that may include few or no acorn-producing oaks (McPherson 1998, Whipple et al. 2010, Peper et al. 2011, Greco and Airola 2018). Given the importance of oaks to scrubjays in natural settings, a scarcity of acorns in urban areas could alter the jay's social organization. For example, Webber (1984) anecdotally reported jays moving beyond territorial boundaries to harvest and cache acorns at an urban-wildland interface in southern California.

As urban habitats expand at the expense of native habitats and agriculture in the Central Valley and elsewhere (Thompson 2007), more information is needed on how wildlife uses urban habitats, what determines species' occurrence and abundance, and how these areas can be designed and managed to support a greater diversity of wildlife (Marzluff et al. 2001, Warren and Lepczyk 2012, Airola and Greco 2019).

In urban Sacramento, I have long observed scrub-jays flying considerable distances with acorns during the fall and winter. In the fall and winter of 2017-18, I characterized these movements to help understand the importance of oaks and jays to each other in this area. Specifically, I sought to quantify the resources of oaks and acorns, to evaluate the extent of urban jays' use of acorns, to quantify the distances the jays traveled to harvest and transport acorns, to quantify the numbers of acorns dispersed, to assess the effect of the sparseness of acorns on the jay's social behavior (especially territoriality), and to identify implications for urban forest management.

\section{STUDY AREA AND METHODS}

The study grew from an initial observation of jays transporting acorns to a broader assessment of the phenomenon over the course of the season. As a result, my methods were somewhat more opportunistic than systematic, as new insights led to my adding further components to the study.

\section{Study Sites}

I studied scrub-jays at four sites within three neighborhoods in urban Sacramento: Midtown, Curtis Park, and East Sacramento (Figure 1; www.cityof sacramento.org/-/media/Corporate/Files/GIS/Maps/Neighborhoods_E. pdf?la=en). The urban forest in these areas consists mostly of a rather dense canopy of older non-native ornamental trees including hybrid London plane (Platanus xacerifolia), American elm (Ulmus americana), deodar cedar (Cedrus deodara), and many other species (McPherson 1998, Peper et al. 2011). Two California native oak species, the local valley oak (Quercus lobata) and coast live oak (Q. agrifolia), make up most of the small component of oak canopy in urban Sacramento (Sacramento Tree Foundation 2007, Greco and Airola 2018). The coast live oak is native to the Coast Ranges just west of Sacramento (Griffin and Critchfield 1972) but occurs in the city 


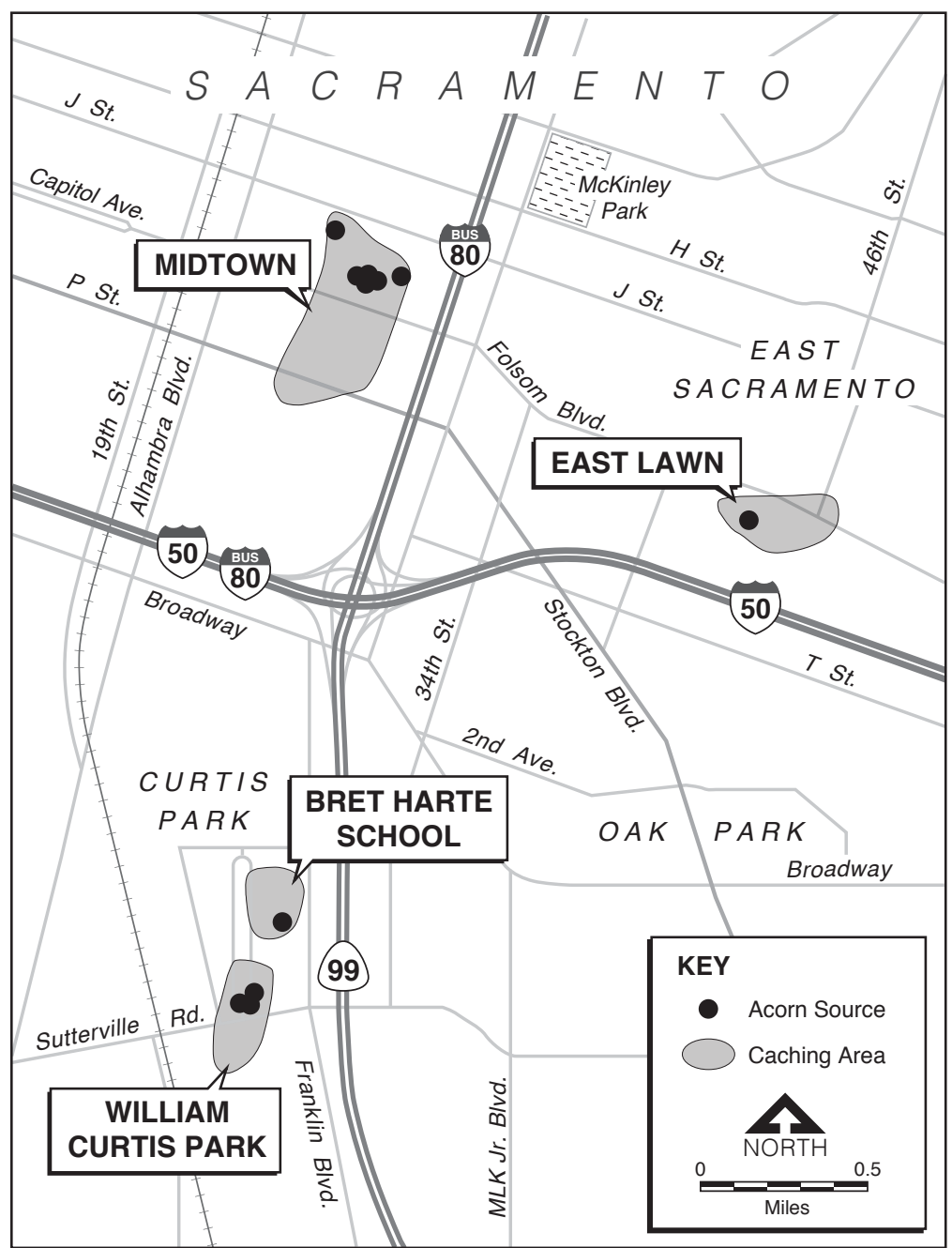

Figure 1. Acorn sources and areas within which California Scrub-Jays were observed to transport and cache acorns at four study sites in urban Sacramento, California.

primarily as a planted cultivar and, in undeveloped areas, as volunteer trees likely established by acorns planted by jays and other acorn dispersers such as the native western gray squirrel (Sciurus griseus) and non-native fox squirrel (S. niger) and eastern gray squirrel (S. carolinensis). I distinguished oaks as human- or animal-planted trees from their location, in highly landscaped and maintained areas or in undeveloped, unmaintained areas, respectively.

Midtown. Most surveys and observations were made within this 54-ha 
older neighborhood (originally built in the mid-to-late 1800s). The area includes mixed commercial and residential buildings and Sutter's Fort, a 3.3-ha historical park that supports a higher density of valley and coast live oaks than the surrounding neighborhood.

Bret Harte School. In its northwest corner, the yard of Bret Harte School in the Curtis Park neighborhood has several large coast live oaks that were likely established from plantings by jays or squirrels. The surrounding area consists of homes constructed from the 1880s to the 1920s (Murphy 2005) and a dense urban forest dominated by London plane but including a variety of other non-native ornamental trees (Peper et al. 2011, Greco and Airola 2018) and a few oaks (see Results).

William Curtis Park. This area includes the southern portion of William Curtis Park and the adjacent neighborhoods of Curtis Park and North City Farms. The park is planted mainly with non-native trees, but valley and coast live oaks are concentrated near Sutterville Road. Adjacent areas include older houses and a dense canopy of non-native trees with few oaks.

East Lawn. East Lawn Cemetery in the East Sacramento neighborhood was established in 1904, and now supports a canopy of tall ornamental trees, especially conifers, and several coast live oaks.

\section{Data Quantification}

Oak Characterization. For each study area I identified the total number of oak trees and, for acorn-bearing trees, the number of each oak species and canopy cover (in hectares, measured horizontally with the ruler/polygon tool in Google Earth Pro). I also calculated the absolute percent canopy cover of bearing oaks by dividing their area by the total area of each study area.

Jay Numbers and Acorn Transport. Throughout the four study areas, I mapped and quantified the jays' movements and the duration of their acorn use. In the Midtown and Bret Harte School neighborhoods, I also plotted jay territories and estimated the numbers of acorns transported by jays. All mean values are reported with standard deviations.

Locations and Movements of Jays. After noticing jays using acorns in the Midtown study area on 18 October 2017, I decided to map the birds' movements to locate the oaks that were the local acorn source. I searched for other nearby areas with oaks to locate acorn-bearing oaks and jays that were transporting acorns. Dates at which monitoring was initiated at other sites varied (see Results). Therefore, the initial dates on which I observed acorn transport in each study area were after the birds had already begun storing acorns.

I walked transects at various distances around oak sources to detect jays commuting to and from acorn sources. The transects were not established systematically but were selected opportunistically in an attempt to be able to detect acorn-transporting jays from all directions and distances around acorn sources. When I observed jays flying toward acorn sources or carrying acorns, I attempted to follow them to destinations where they harvested acorns or stored or consumed them. I plotted observed flight segments of such movements on aerial photos in the field. Because I knew the locations of acorn sources, I could add an inferred path segment to many flights (i.e., the path from the first or last observation of the bird to the acorn source). 
I measured the distances of complete and incomplete flights by using the path-distance tool in Google Earth.

To quantify the frequency of flights over the season and estimate the jays' total use of acorns, I recorded the numbers of commuting flights observed while I walked each transect. As the birds used different routes to travel to and from acorn sources, I calculated flight frequencies (number of trips per hour) in only two areas: a frequently used corridor in Midtown and the entire Bret Harte School site.

As did Carmen (2004:18-19) in coastal California oak woodlands, I observed that many California Scrub-Jays in Sacramento actively defended territories during the fall and early winter study period, within which they cached their harvested acorns. I mapped territories by plotting the jays' locations over the study period on the basis of their locations (within $7 \mathrm{~m}$ of the ground; commuting jays fly at greater heights; see Results) and behaviors (caching acorns, foraging on the ground, behaving aggressively near other jays). I estimated territory boundaries from locations of territorial interactions, simultaneous observations of multiple jays, and concentrations of observations, and then measured the area with Google Earth's polygon function. From these information sources, it was relatively easy to determine the number of territorial birds commuting to acorn sources, but because it was more difficult to map precise territorial boundaries, in calculating territory sizes I only used a subset of territories with $>2$ observations of interterritorial interactions.

Duration of acorn use. The dates on which I first observed acorn transport at each site were somewhat opportunistic, and thus almost surely later than the true date on which acorn harvest began. Because all harvested acorns were from coast live oaks, I assumed that acorns became available and jays began transporting them on the same date. Therefore, I conservatively assigned 18 October, the date of first observed acorn transport in my study areas, as the first date of transport at all sites. Following first detection of transport at each site, I documented the duration of acorn use through the following winter. For each site, I identified the end date for transport as the last date when transport was observed and followed by three dates when no transport was seen.

Numbers of jays using acorn sources. I estimated the numbers of jays using acorn sources at the Midtown and Bret Harte School study areas, the two sites where I made the most observations (64\% and 24\%, respectively). At each site, I estimated the number of jays using acorn sources from the combination of simultaneous observations of individuals, the numbers of territorial jays that transported acorns in various directions to territories, and counts of nonterritorial floaters (Carmen 2004). There was no way to unambiguously distinguish territorial and nonterritorial birds during flights to and from acorn sources, so I assumed that territory holders would be traveling singly or in pairs and conservatively counted only groups of $\geq 3$ individuals traveling together as floaters.

Numbers of acorns dispersed by jays. I the estimated numbers of acorns dispersed per individual at the Midtown and Bret Harte School sites. Because birds were not marked, I could not directly record rates of acorn dispersal by individuals. Therefore, I indirectly estimated the number of acorns distributed 
at each site from the number of territorial birds and floaters that traveled a regularly monitored route to and from the acorn sources. I first calculated rates of transport (mean number of trips per hour) from observations at various times of day and dates over the season. I then calculated the total number of acorns dispersed at each site as

$(\bar{x}$ trips $/ \mathrm{hr}) \times(\bar{x}$ daylight $\mathrm{hr} /$ day $) \times(n$ days during which acorns were cached $)$.

The average number of acorns dispersed per individual at each of the two sites was then calculated as the total number of acorns dispersed at the site divided by the number of jays at each site.

\section{RESULTS}

\section{Oak Canopy and Acorn Abundance}

Within the study areas, the oaks comprised the coast live oak, valley oak, and non-native ornamental species (Table 1). I inferred that two (4\%) of the 42 oak trees in Midtown, of which one produced acorns, originated from acorns planted by jays. Six of the seven trees (86\%) in the Bret Harte School study area were apparently jay- or squirrel-planted, including the two trees from which jays harvested acorns there.

During 2017, only 24 oak trees (19\%) within the four study areas produced acorns, of which 22 (92\%) were coast live oaks (Table 2). Valley oak had a nearly complete failure of the acorn crop in 2017, with only two trees (4\%) producing acorns. No non-native oaks, including the cork oak (Q. suber; $n=2)$, scarlet oak $(Q$. coccinea; $n=16)$, and southern white oak ( $Q$. alba; $n=5$ ), produced acorns. Oaks that bore acorns in 2017-18 represented $\leq 1 \%$ of the canopy cover in the study areas (Table 2 ).

\section{Jay Flight Behavior and Distances}

From the first incidental observation on 14 October, I noted jays transporting acorns through 12 February, thus for a minimum of 117 days. The end dates for acorn transport varied substantially by site (Table 3), which appeared to reflect acorn abundance and the duration of acorn availability.

The distance of each leg of a California-Scrub Jay's flight to and from acorn sources appeared limited. Birds generally traveled their routes by flying a set of 40-125-m legs between a succession of high (20-35 m) perches in

Table 1 Numbers and Cover of Oaks and Acorn-Bearing Oaks by Species in Four Study Areas in Urban Sacramento

\begin{tabular}{lcrcc}
\hline & & \multicolumn{3}{c}{ Acorn-bearing trees } \\
\cline { 3 - 5 } Species & All trees $(n)$ & $n$ & Canopy area (ha) & $\begin{array}{c}\text { Relative canopy } \\
\text { cover (\%) }\end{array}$ \\
\hline Coast live oak & 51 & 22 & 0.29 & 97 \\
Valley oak & 52 & 2 & 0.01 & 3 \\
Non-native oaks & 21 & 0 & 0 & 0 \\
Total & 126 & 24 & 0.30 & 100 \\
\hline
\end{tabular}


Table 2 Numbers and Cover of Acorn-Bearing Oaks at Four Study Areas in Sacramento

\begin{tabular}{lcrcc}
\hline & & \multicolumn{3}{c}{ Acorn-bearing trees } \\
\cline { 3 - 5 } Site & $\begin{array}{c}\text { Extent of } \\
\text { study area (ha) }\end{array}$ & $n$ & Canopy area (ha) & $\begin{array}{c}\text { Absolute canopy } \\
\text { cover (\%) }\end{array}$ \\
\hline Midtown & 54 & 10 & 0.13 & 0.25 \\
Bret Harte & 6 & 2 & 0.03 & 0.46 \\
Curtis Park & 9 & 10 & 0.11 & 1.18 \\
East Lawn & 11 & 2 & 0.03 & 0.25 \\
Total & 80 & 24 & 0.30 & 0.37 \\
\hline
\end{tabular}

Table 3 Chronology of California Scrub-Jays Transporting Acorns at Four Sites in Sacramento, 2017-2018

\begin{tabular}{lcccc}
\hline Site & $\begin{array}{c}\text { First date } \\
\text { transport } \\
\text { observed }^{a}\end{array}$ & $\begin{array}{c}\text { Last date } \\
\text { transport } \\
\text { observed }\end{array}$ & $\begin{array}{c}\text { Duration of } \\
\text { observed } \\
\text { transport (days) }\end{array}$ & $\begin{array}{c}\text { Inferred duration } \\
\text { of transport } \\
\text { (days from 18 Oct) }\end{array}$ \\
\hline Midtown & 18 Oct & 12 Feb & 117 & 117 \\
Bret Harte & 4 Jan & 26 Jan & 22 & 100 \\
Curtis Park & 27 Nov & 11 Jan & 45 & 85 \\
East Lawn & 28 Nov & 30 Nov & 2 & 43 \\
\hline
\end{tabular}

${ }^{a}$ The first date of observed transport at each site also was the date when monitoring was initiated there; thus transport likely occurred before the date of first observation at each site.

the tops of overstory trees, including American elms, London planes, and deodar cedars, stopping up to seven times on longer trips.

I recorded 119 complete or partial flights to acorn sources and 151 flights from sources. Only 35 (13\%) flights between acorn sources and territories were directly observed in their entirety, but I was able to project the total distance for 40 additional flights (15\%) from knowledge of the acorn source used ("complete flights"). Thus 72\% (195) of recorded flights were partial flights (i.e., starting point and/or destination uncertain; Figure 2).

Distances of the 35 observed complete flights averaged $90 \mathrm{~m}( \pm 35 \mathrm{~m})$, while distances for the 195 recorded partial flights averaged $142 \mathrm{~m}( \pm 195$ $\mathrm{m})$, demonstrating that the complete flights observed were a biased subset of all flights. Flight distances for the 75 complete flights (observed and inferred pooled) averaged $175 \mathrm{~m}( \pm 130 \mathrm{~m})$. The longest recorded flight was $665 \mathrm{~m}$, equivalent to seven city blocks (Figures 1 and 2).

Acorn-transporting jays' use of high perches while passing above the territories of other pairs did not elicit territorial defense. Also, I seldom noted territorial disputes at acorn sources. Jays that appeared to be occupying the territories that contained the acorn sources sometimes showed aggression, but more often tolerated the presence of other jays nearby.

\section{Numbers of Scrub-Jays Using Acorn Sites}

In the 17.5-ha Midtown area (about 11 city blocks), I plotted 86 scrubjay locations in eight territories from which birds traveled to harvest acorns. 


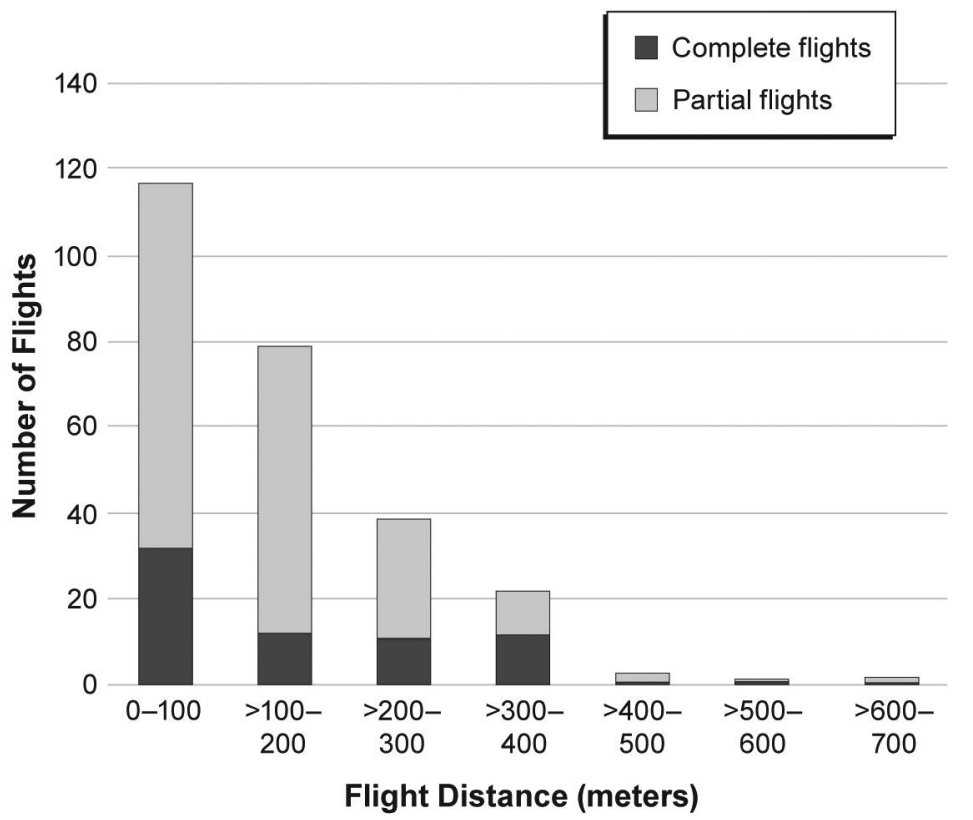

Figure 2. Number of completely and partially recorded flights by distance class of California Scrub-Jays tranporting acorns in urban Sacramento, California.

Four territories with observations sufficient for boundaries to be plotted averaged an estimated 1.99 ha ( \pm 0.19 ha). I observed additional birds, often in groups of three or four, likely nonterritorial floaters (Carmen 2004), that also transported acorns. Therefore, at least 20 scrub-jays (16 territorial birds and 4 floaters) used the Midtown acorn source.

Because of the configuration of streets at the Bret Harte School study area (4.7 ha or about 6 city blocks), it was more difficult to follow commuting flights of scrub-jays. I plotted 52 locations within territories of birds estimated to occupy five territories. Four territories with a number of observations sufficient for boundaries to be plotted averaged 1.02 ha $( \pm 0.10)$. From the number of territories from which birds commuted to acorns, counts of individuals at the acorn source, and mapped flight directions and distances, I estimate a minimum of 13 birds used the Bret Harte School acorn source.

Numbers of Acorns Dispersed by Scrub-Jays

At the most intensively studied Midtown area, I recorded an average of 5.9 trips per hour made by the estimated 20 jays ( \pm 0.3 trips/bird/hr). With an average of 9.5 hours of daylight over the minimum 117 days that jays transported acorns, I project that 6800 acorns were transported from this site, or an average of 340 acorns per bird for the season. At Bret Harte School, the minimum population of 13 jays made an average of 11.7 trips/ hr $( \pm 0.9$ trips/bird/hr) during the January monitoring period there. If this 
rate of transport continued throughout the 104-day harvest period (Table 2), jays transported an estimated 11,000 acorns from this site, or an average of 840 acorns per jay over the season.

\section{DISCUSSION}

Notwithstanding the rarity of bearing oaks in urban Sacramento, I found that many California Scrub-Jays made extensive use of available acorn sources and traveled substantial distances, crossing territorial boundaries, to harvest and cache acorns.

My characterizations of other aspects of acorn harvest, transport, and caching relied to a substantial degree on certain assumptions and interpretations that were unavoidable given the observational nature and urban setting of the study. While I consider the approaches used to be conservative and thus relatively accurate, additional precision and certainty could be achieved through study of marked birds and tracking via telemetry.

Characterizing flight distances to and from acorn sources was hampered by obstructions to access and visibility in the urban setting, as well as the difficulty of following birds on foot during their trips. Thus the partial-flight distances I report are underestimates of total flight distances. The fact that the average flight distance for complete trips was less than for partial flights shows that recorded complete flights were a shorter, biased sample of all flights. Therefore, my recording of flights disproportionately sampled birds whose cache sites were close to acorn sources, and underestimated flight distances. Despite these limitations, the distances of observed and projected complete flights demonstrate that urban California Scrub-Jays commuted an average of $>175 \mathrm{~m}$, and up to $665 \mathrm{~m}$, to harvest and cache acorns.

The distances over which California Scrub-Jays dispersed acorns in urban Sacramento exceed those reported for the California Scrub-Jay in coastal California oak woodlands and the Island Scrub-Jay in chaparral with oaks. In oak woodlands, Carmen (2004) found that territorial California ScrubJays harvested and cached acorns only from within their territories, which averaged 2.2-2.5 ha in size (i.e., an average diameter and therefore rough maximum travel distance of $170 \mathrm{~m}$ ). Pesendorfer et al. (2016b) reported Island Scrub-Jays dispersing acorns an average distance of $38 \mathrm{~m}$, and a maximum of $400 \mathrm{~m}$, from the source.

Numbers of acorns cached annually by individual jays in urban Sacramento were substantially lower than in coastal oak woodlands (340 and 840 at the two areas where I evaluated it versus 7000; Carmen 2004). This difference may reflect fewer acorns being available, more time required to harvest and transport urban acorns to more distant cache sites, and the availability of alternative foods in urban areas.

Territorial California Scrub-Jays spend most of their time in understory trees and shrubs (Curry et al. 2017; pers. obs.). In urban Sacramento, jays that defended their territories from other jays near the ground throughout the fall-winter study period routinely ignored jays that transported acorns by overflying their territories at treetop height of 25-35 m. These observations suggest an upper height to the area a California Scrub-Jay defends as a territory. 
The jays' regular flights outside their territories in urban areas contrasts with the pattern Carmen (2004) found in coastal oak woodlands, where $97 \%$ of observations of territory holders were within their territories. This behavioral variation likely results from the differences in the abundance of acorns and other food sources in these two environments as well as the birds' ability to cross above the areas defended by territorial jays. Oaks are abundant within jay territories in coastal woodland. In contrast, many scrub-jay territories in Sacramento lacked oaks altogether or contained only oaks that failed to bear in 2017-18. Urban areas also likely provide additional foods unavailable in natural woodlands, including fruits and nuts from ornamental plants and bird seed. The patchy distribution of bearing oaks, and the jays' possible lesser dependence on acorns, also may have discouraged jays from defending their territories from other jays commuting to acorn sources.

The extended duration ( $>117$ days) of acorn caching demonstrates its importance to jays in this urban area. Although my anecdotal observations suggest that acorn caching is widespread in Sacramento, it is not clear if all urban Sacramento scrub-jays use acorns. Further study would be worthwhile to evaluate the extent of acorn dependence as the supply of acorns varies, including absence, and whether the availability of acorns increases local population density or reproductive success.

The methods I used to quantify frequency of observed trips by scrub-jays to harvest acorns (observed trips per hour of all birds) in Sacramento is not directly comparable to rates reported for the Island Scrub-Jays individually marked by Pesendorfer et al. (2016b). However, my observing an average of only 0.3-0.9 caching trips per bird per hour, while Island Scrub-Jays on Santa Cruz Island cached an average of 7.2 acorns per bird per hour, suggests that they cached more acorns than did the Sacramento birds. Lower rates of acorn dispersal by Sacramento birds may result from the greater time needed to transport acorns longer distances and the use of a wide variety of foods in the urban environment (Curry et al. 2017).

Whereas jays' dispersal of acorns contributes importantly to the regeneration of woodland in wild ecosystems (Pesendorfer et al. 2016a, b), its effects are more limited in urban settings. Many cached acorns sprout and grow in urban and suburban gardens, where most gardeners treat them as weeds and remove them. Nonetheless, jays' caching of acorns in less intensively managed areas (e.g., vacant lots, ditches, road and utility rights-of ways, wildland parks) contributes to the maintenance of a moderate amount of oak canopy in the urban and suburban landscape. For example, jays were likely responsible, perhaps along with squirrels, for establishing a 1.3-ha valley oak woodland at the Curtis Park Railyard, which was used intensively by migratory passerines (Greco and Airola 2018) before it was destroyed for redevelopment. Considering the substantial cost of establishing oaks in urban Sacramento (mean $\$ 250$ per tree, Wyly and Teach 2015), research may be warranted to identify ways in which jays may contribute to establishing oaks less expensively in desirable locations.

My documentation of urban California Scrub-Jays' substantial use of acorns supports the value of oaks to this species in urban settings, but also the potential benefits of oak dispersal by jays to other acorn-consuming species and to insectivorous birds (McShea and Healy 2002, Greco and Airola 
2018, Airola and Greco 2019). I recommend greater consideration of oaks in urban tree plantings, protection of existing oaks, and maintenance and encouragement of jay-planted oaks, where feasible, to increase the urban oak canopy.

\section{ACKNOWLEDGMENTS}

I thank Layla Airola for field assistance and useful discussion and Paul Cylinder and Zarah Wyly for discussion and assistance in identifying non-native oaks. Mario Pesendorfer, Kachina Rowland, and Robert Gill provided insightful review comments that substantially improved the paper.

\section{LITERATURE CITED}

Airola, D. A., Hampton, S, and Manolis, T. 2007. Effects of West Nile virus on sensitive species in the lower Sacramento Valley, California: An evaluation using Christmas Bird Counts. Central Valley Bird Club Bull. 10:1-23.

Airola, D. A., and Greco, S. E. 2019. Birds and oaks in California's urban forest. International Oaks 30:109-116.

Beedy, E. C., and Pandolfino, E. R. 2013. Birds of the Sierra Nevada: Their Natural History, Status, and Distribution. Univ. of Calif. Press, Berkeley.

Blair, R. B. 1996. Land use and avian species diversity along an urban gradient. Ecol. Appl. 6:506-519; doi 10.2307/2269387.

Caldwell, L., Bakker, V. J., Sillett, T. S., Desrosiers, M. A., Morrison, S. A., and Angeloni, L. M. 2013. Reproductive ecology of the Island Scrub-Jay. Condor 115:603-613; doi 10.1525/cond.2013.120028.

Carmen, W. J. 2004. Noncooperative breeding in the California Scrub-Jay. Studies Avian Biol. 28:1-100.

Clemens, S. L. 1875. The Innocents Abroad. Hartford Publ. Co., Hartford, CT.

Curry, R. L., and Delaney, K. S. 2002. Island Scrub-Jay (Aphelocoma insularis), in The Birds of North America (A Poole and F. Gill, eds.), no 713. Birds N. Am., Inc., Philadelphia; doi 10.2173/bna.713.

Curry, R. L, Peterson, A. T., Langen, T. A., Pyle, P., and Patten, M. A. 2017. California Scrub-Jay (Aphelocoma californica), version 3.0, in The Birds of North America (P. G. Rodewald, ed.). Cornell Lab Ornithol., Ithaca, NY; doi 10.2173/bna.cowscj1.03.

DeGange, A. R., Fitzpatrick, J. W., Layne, J. N. and Woolfenden, G. E. 1989. Acorn harvesting by Florida Scrub Jays. Ecology 70:348-356; doi 10.2307/1937539.

Greco, S. E., and Airola, D. A. 2018. The importance of native valley oaks (Quercus lobata) as stopover habitat for migratory songbirds in urban Sacramento, California, USA. Urban Forestry and Urban Greening 29:303-311; doi 10.1016/j. ufug.2018.01.005.

Griffin, J. R. 1971. Oak regeneration in the upper Carmel Valley, California. Ecology 52:862-868; doi 10.2307/1936034.

Griffin, J. R., and Critchfield, W. B. 1972. The distribution of forest trees in California. U.S. Dept. Agric. Forest Service Res. Paper PSW 82. Pacific Southwest Forest and Range Experiment Station, Berkeley, CA.

Grinnell, J. 1936. Uphill planters. Condor 38:80-82; doi 10.2307/1363554.

Marzluff, J. M., Bowman, R., and Donnelly, R. 2001. Avian Ecology and Conservation in an Urbanizing World. Kluwer Academic, Norwell, MA; doi 10.1007/978-14615-1531-9.

McPherson, E. G. 1998. Structure and sustainability of Sacramento's urban forest. J. Arboriculture 24:174-190. 
McShea, W. J., and Healy, W. M. 2002. Oak Forest Ecosystems: Ecology and Management for Wildlife. Johns Hopkins Univ. Press, Baltimore.

Morrison, S. A., Sillett, T. S., Ghalambor, C. K., Fitzpatrick, J. W., Graber, D. M., Bakker, V. J., Bowman, R., Collins, C. T., Collins, P. W., Semple Delaney, K., Doak, D. F., Koenig, W. D., Laughrin, L., Lieberman, A. A., Marzluff, J. M., Reynolds, J. D., Scott, J. M., Stallcup, J. A., Vickers, W., and Boyce, W. M. 2011. Proactive conservation management of an island-endemic bird species in the face of global change. BioScience 61:1013-1021; doi 10.1525/bio.2011.61.12.11.

Murphy, D. 2005. Images of America: Sacramento's Curtis Park. Arcadia Publ., San Francisco.

Pandolfino, E. R. 2017. Continuing impacts of West Nile virus on birds of California's Central Valley. Central Valley Bird Club Bull. 20:101-109.

Peper, P. J., Vargas, K. E., and McPherson, E. G. 2011. Sacramento's park neighborhood trees. StoneBridge Properties LLC, Sacramento.

Pesendorfer, M. B., Sillett, T. S., Koenig, W. D., and Morrison, S. A. 2016a. Scatterhoarding corvids as seed dispersers for oaks and pines: A review of a widely distributed mutualism and its utility to habitat restoration. Condor 118:215-237; doi 10.1650/CONDOR-15-125.1.

Pesendorfer, M. B., Sillett, T. S., Morrison, S. A., and Kamil, A. C. 2016b. Contextdependent seed dispersal by a scatter-hoarding corvid. J. Anim. Ecol. 85:798805; doi 10.1111/1365-2656.12501.

Sacramento Tree Foundation. 2007. Guide to Sacramento Oaks. Sacramento Tree Foundation, Sacramento; www.sactree.com/assets/GuideToSacramentoOaks4.pdf.

Thompson, E. Jr. 2007. Paving Paradise: A New Perspective on California Farmland Conversion. Am. Farmland Trust, Washington, DC.

Warren, P. S., and Lepczyk, C. A. 2012. Beyond the gradient: Insights from new work in the avian ecology of urbanizing lands. Studies Avian Biol. 45; doi 10.1525/ california/9780520273092.003.0001.

Webber, T. 1984. Form and function of the long-range calls of Scrub Jays, Aphelocoma coerulescens obscura. Ph.D. Thesis, Univ. of Fla., Gainesville.

Wheeler, S. S., Barker, C. M., Fang, Y., Armijos, M. V., Carroll, B. D., Husted, S., Johnson, W. O., and Reisen, W. K. 2009. Differential impact of West Nile virus on California birds. Condor 111:1-20; doi 10.1525/cond.2009.080013.

Whipple, A., Grossinger, R. M., and Davis, F. W. 2010. Shifting baselines in a California oak savanna: Nineteenth century data to inform restoration scenarios. Restoration Ecol. 19:88-101; doi 10.1111/j.1526-100X.2009.00633.x.

Woolfenden, G. E., and Fitzpatrick, J. W. 1996. Florida Scrub-Jay (Aphelocoma coerulescens), in The Birds of North America (A. Poole and F. Gill, eds.), no. 228. Acad. Nat. Sci., Philadelphia; doi.org/10.2173/bna.228.

Wyly, Z., and Teach, T. 2015. Urban Sacramento oak reforestation: 17 years and 20,000 trees, in Proceedings of the seventh California oak symposium: Managing oak woodlands in a dynamic world (R. B. Standiford and K. L Purcell, tech. coords.), pp. 447-454. U.S. Dept. Agric. Forest Service Gen. Tech. Rep. PWS-GTR-251. 